\title{
PENGEMBANGAN MODUL MATEMATIKA DENGAN PENDEKATAN METAKOGNITIF UNTUK MEMFASILITASI KEMANDIRIAN BELAJAR SISWA SMK MUHAMMADIYAH KUPANG
}

\author{
Ryan Nizar Zulfikar ${ }^{1 \circledast}$ dan Muhammad Tamrin ${ }^{2}$ \\ ${ }^{1}$ Jurusan Pendidikan Matematika, Universitas Muhammadiyah Kupang \\ ${ }^{2}$ Jurusan Tarbiyah, Universitas Muhammadiyah Kupang
}

\section{Info Artikel Abstract}

Sejarah Artikel:

Diterima 12 Sept 2019

Direvisi 24 Okt 2019

Disetujui 6 Nov 2019

Keywords: Mathematics,

Metacognitive, Module,

Development

Paper type:

Research paper
The purpose of this study is to: Analyze the Development of Mathematical Modules with a Metacognitive Approach to Facilitate Learning Independence of SMK Muhammadiyah Kupang Students. This research is a research development. The research method used is a research and development method. The location that is the object of research is the Muhammadiyah Kupang Vocational School. Subjects taken in this study were students of class X-A SMK Muhammadiyah Kupang. Data collection methods used were validation sheets and questionnaires. Data analysis techniques in this study were carried out by means of validation analysis of quantitative data derived from assessment sheets (validation) from media experts in the form of average scores and then converted to a qualitative scale. The results of media and material assessment validation on the mathematics module with a metacognitive approach are very valid with an average of 3.4. Thus this teaching material is very feasible to be used as teaching material. The results of the development of the module with a metacognitive approach can also be seen from students' responses, namely the student response questionnaire states that an average of 3.58 is obtained and can be categorized as receiving very good responses from students. Based on the module's success criteria seen from the average number of students whose responses are very good then, the mathematics module media with a metacognitive approach can be said to be successful.

\begin{abstract}
Abstrak
Tujuan dari penelitian ini adalah: menganalisis pengembangan modul matematika dengan pendekatan metakognitif untuk memfasilitasi kemandirian belajar siswa SMK Muhammadiyah Kupang. Penelitian ini merupakan penelitian pengembangan. Metode penelitian yang digunakan adalah metode penelitian dan pengembangan. Lokasi yang menjadi objek penelitian adalah SMK Muhammadiyah Kupang. Subyek yang diambil pada penelitian ini adalah siswa kelas X-A SMK Muhammadiyah Kupang. Metode pengumpulan data yang digunakan adalah lembar validasi dan angket. Teknik analisis data dalam penelitian ini dilakukan dengan cara analisis validasi dari data kuantitatif yang berasal dari lembar penilaian (validasi) dari ahli media berupa skor rata-rata kemudian diubah menjadi skala kualitatif. Hasil validasi penilaian media dan materi pada "modul matematika dengan pendekatan metakognitif" dikatakan sangat valid dengan rata-rata 3,4. Dengan demikian bahan ajar ini sangat layak digunakan sebagai bahan ajar. Hasil pengembangan modul dengan pendekatan metakognitif dapat juga dilihat dari repon siswa yaitu angket respon siswa menyebutkan bahwa didapat rata-rata 3,58 dan dapat dikategorikan mendapat respon sangat baik dari siswa. Berdasarkan kriteria keberhasilan modul dilihat dari rata-rata banyaknya siswa yang responnya sangat baik maka, media modul matematika dengan pendekatan metakognitif dapat dikatakan berhasil.
\end{abstract}

(C) 2019 Universitas Muria Kudus

\begin{tabular}{ll}
\hline Alamat korespondensi: & p-ISSN 2615-4196 \\
Program Studi Pendidikan Matematika & e-ISSN 2615-4072 \\
Fakultas Keguruan dan Ilmu Pendidikan Universitas Muria Kudus &
\end{tabular}

Kampus UMK Gondangmanis, Bae Kudus Gd. L. It I PO. BOX 53 Kudus

Tlp (0291) 438229 ex.147 Fax. (0291) 437198

E-mail: rnzulfikar1993@gmail.com 


\section{PENDAHULUAN}

Pembelajaran matematika saat ini sangat membutuhkan seorang pendidik yang mempunyai dedikasi yang tinggi dalam menjalankan tugas profesionalnya. Namun terdapat suatu masalah yang dihadapi di dalam pendidikan kita bahwa masih lemahnya proses pembelajaran (Danuri, 2014). Selain itu, faktor lain yang dapat mempengaruhi rendahnya proses pembelajaran siswa adalah kompetensi yang dimiliki guru tersebut masih tergolong rendah, sehingga memperlihatkan bahwa dalam proses belajar dan mengajar, guru berperan dominan dan informasi hanya berjalan satu arah dari guru ke siswa, sehingga siswa sangat pasif (Shimada,2006;Anisa 2014;Rahmania 2014). Untuk mencapai tujuan pembelajaran matematika, salah satunya siswa memerlukan pengalaman dalam menyelesaikan suatu permasalahan matematika. Agar siswa dapat mengalami sendiri bagaimana menyelesaikan suatu permasalahan,maka siswa memerlukan kegiatan menyelesaikan maslah itu sendiri. Pada saat observasi kesekolah SMK Muhammadiyah Kupang, kepala sekolah yang sekaligus guru matematika menerangkan bahwa dalam proses pembelajaran matematika, informasi yang diterima hanya satu arah (dari guru ke siswa) dan menggunakan diskusi kelompok untuk menyelesaikan masalah matematika.

Solusi yang perlu dipertimbangkan adalah penggunaan bahan ajar modul dalam proses pembelajaran. Dengan sistem pembelajaran modul ini, siswa mendapat kesempatan lebih banyak untuk belajar sendiri, membaca uraian, dan petunjuk di dalam lembaran kegiatan, dan menjawab pertanyaan-pertanyaan serta melaksanakan tugas-tugas yang harus diselesaiakan dalam setiap tugas. Modul merupakan suatu unit program pengajaran yang disusun dalam bentuk tertentu untuk keperluan belajar. Pada kenyataannya modul merupakan jenis kesatuan kegiatan belajar yang terencana, dirancang untuk membantu para siswa secara individual dalam mencapai tujuan belajarnya. Modul yang dikembangkan harus mampu meningkatkan motivasi peserta didik. Untuk menghasilkan modul yang baik, ada lima kriteria yang ditetapkan yaitu Self Instructional, Self Contained, Stand Alone, Adaptive, User Friendly (Arsyad,2011). Untuk lebih jelasnya dapat dilihat pembahasannya sebagai berikut: Self Instructional; yaitu mampu membelajarkan peserta didik secara mandiri. Self Contained; yaitu materi belajar dari satu unit kompetensi atau sub kompetensi yang dipelajari terdapat di dalam satu modul secara utuh. Stand Alone ( berdiri sendiri ); yaitu modul yang dikembangkan tidak tergantung pada media lain atau tidak harus digunakan bersama-sama dengan media pembelajaran lain. Adaptive; modul hendaknya dapat menyesuaikan perkembangan ilmu pengetahuan dan teknologi, serta fleksibel digunakan. User Friendly; modul hendaknya bersahabat dengan pemakainya artinya penggunaan bahasa yang sederhana, mudah dimengerti serta penampilan gambar yang sesuai dengan selera peserta didik, itu merupakan salah satu bentuk User Friendly .

Modul matematika dengan pendekatan metakognitif, memuat materi-materi matematika yang dirangsang melalui proses pembelajaran disertai dengan aspek-aspek metakognitif diantaranya aspek kesadaran dimana modul yang dikembangkan berupa pengenalan kembali materi yang telah diketahui sebelumnya, aspek strategi kognitif dimana modul yang dikembangkan menggunakan strategi memahami masalah dan menyelesaikan masalah, aspek perencanaan dimana modul yang dikembangkan mengingatkan kembali kepada peserta didik untuk mempersiapkan strategi kognitif untuk memahami materi yang hendak dipelajari, aspek mengevaluasi kerjanya sendiri dimana jika diperoleh kesalahan maka dapat membetulkan kesalahan tersebut (Nugrahaningsi, 2012; In'am, 2012). Setelah memahami permasalahan-permasalahan $\mathrm{di}$ atas, peneliti termotivasi untuk mengembangkan sumber belajar yang dapat meminimalkan suasana kurang kondusif dalam pembelajaran. Pengembangan modul matematika merupakan salah satu langkah penting untuk membangun fondasi bagi keilmuan matematika dan keimuan lain yang dipelajari siswa pada tahap lebih lanjut. Oleh karena itu Rumusan Masalahnya Bagaimana Pengembangan Modul Matematika Dengan Pendekatan Metakognitif Untuk Memfasilitasi Kemandirian Belajar Siswa SMK Muhammadiyah Kupang, dan Tujuan dari penelitian ini adalah: Menganalisis Pengembangan Modul Matematika Dengan Pendekatan Metakognitif Untuk Memfasilitasi Kemandirian Belajar Siswa Smk Muhammadiyah Kupang

\section{METODE PENELITIAN}

Alur Prosedur Penelitian yang dilakukan oleh peneliti yaitu sebagai berikut. 


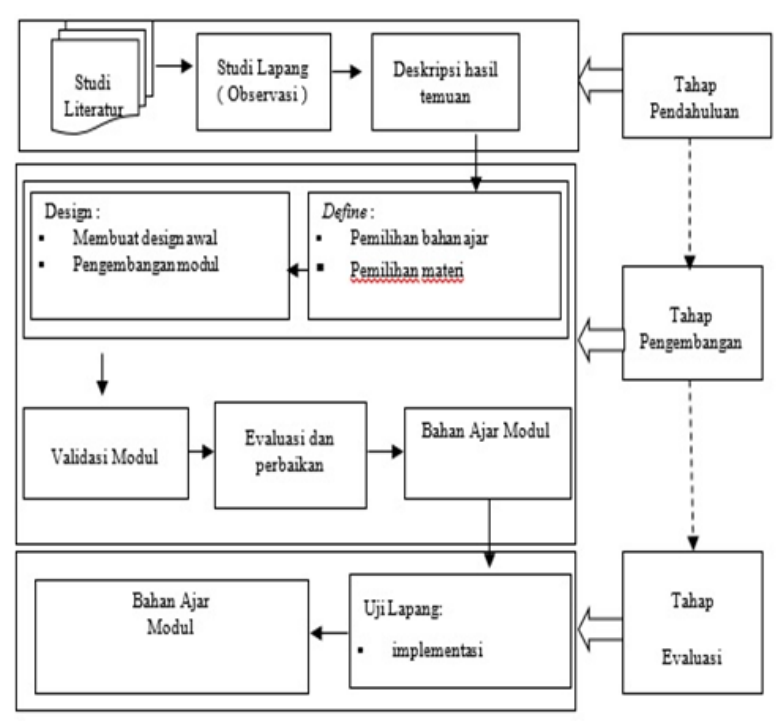

Gambar 1. Alur Prosedur Penelitian

Penelitian ini merupakan penelitian pengembangan. Metode penelitian yang digunakan adalah metode penelitian dan pengembangan. Metode pengumpulan data yang digunakan adalah lembar validasi dan angket. Angket dilakukan pada tahap validasi dan uji coba terbatas, pada tahap validasi angket diisi oleh dua dosen ahli dan satu orang guru matematika sebagai penilaian modul yang hasilnya dijadikan acuan oleh peneliti untuk mengembangkan modul yang lebih efektif dan efisien, sedangkan pada tahap uji coba terbatas peneliti ingin mengetahui respon siswa terhadap modul yang dikerjakan.

Teknik analisis data dalam penelitian ini dilakukan dengan analisisis data kualitatif dan kuantitatif dimana cara analisis validasi dari data kuantitatif yang berasal dari lembar penilaian (validasi) dari ahli media dan lembar respon siswa berupa skor rata-rata ( $\quad \square$ ) kemudian diubah menjadi skala kualitatif sebagai kesimpulan untuk melihat modul yang dikembangkan efektif atau tidak digunakan dalam proses pembelajaran. Untuk mengetahui peringkat nilai akhir untuk butir yang bersangkutan, jumlah nilai tersebut harus dibagi dengan banyaknya responden yang menjawab angket tersebut.

\section{HASIL DAN PEMBAHASAN}

Analisis dimulai dengan mencari rata-rata tiap sub-aspek dengan menjumlahkan hasil validasi dari kedua validator dan membaginya dengan banyaknya validator, menghitung ratarata tiap aspek dengan menjumlah rata-rata sub- aspek tiap aspeknya dan membaginya dengan banyaknya sub-aspek tiap aspeknya. Dari hasil rata-rata tiap aspek kemudian menentukan kategori kevalidan dengan mencocokkan ratarata persentase skor tiap aspek dengan kategori kevalidan yang ditetapkan. Lembar validasi ini dapat dilihat pada tabel dibawah ini.

Tabel 1. Analisis Kevalidan Modul Oleh Para Ahli

\begin{tabular}{|c|c|c|c|c|c|c|}
\hline \multirow[t]{2}{*}{ NO } & \multirow[t]{2}{*}{ Aspek } & \multicolumn{2}{|c|}{$\begin{array}{c}\text { Skor } \\
\text { Validator }\end{array}$} & \multirow{2}{*}{$\begin{array}{c}\text { Rata- } \\
\text { rata } \\
\text { sub } \\
\text { aspek }\end{array}$} & \multirow[t]{2}{*}{ Ket } & \multirow{2}{*}{$\begin{array}{c}\text { Rata- } \\
\text { rata } \\
\text { tiap } \\
\text { aspek }\end{array}$} \\
\hline & & $x_{1}$ & $x_{2}$ & & & \\
\hline \multirow[t]{7}{*}{1} & Aspek & 3 & 4 & 3,5 & SV/TPR & \multirow{7}{*}{3,4} \\
\hline & Bahasa & 3 & 4 & 3,5 & SV/TPR & \\
\hline & & 3 & 4 & 3,5 & SV/TPR & \\
\hline & & 3 & 4 & 3,5 & SV/TPR & \\
\hline & & 3 & 3 & 3 & $\mathrm{~V} / \mathrm{PR}$ & \\
\hline & & 3 & 4 & 3,5 & SV/TPR & \\
\hline & & 4 & 3 & 3,5 & SV/TPR & \\
\hline \multirow[t]{3}{*}{2} & Aspek & 3 & 3 & 3 & $\mathrm{~V} / \mathrm{PR}$ & \multirow{3}{*}{$\mathbf{3 , 3}$} \\
\hline & contoh dan & 4 & 4 & 4 & SV/TPR & \\
\hline & soal latihan & 3 & 3 & 3 & $\mathrm{~V} / \mathrm{PR}$ & \\
\hline \multirow[t]{7}{*}{3} & Aspek & 3 & 4 & 3,5 & SV/TPR & \multirow{7}{*}{3,5} \\
\hline & materi & 3 & 3 & 3 & V/PR & \\
\hline & & 4 & 3 & 3,5 & SV/TPR & \\
\hline & & 4 & 4 & 4 & SV/TPR & \\
\hline & & 3 & 3 & 3 & $\mathrm{~V} / \mathrm{PR}$ & \\
\hline & & 3 & 4 & 3,5 & SV/TPR & \\
\hline & & 4 & 4 & 4 & SV/TPR & \\
\hline 4 & $\begin{array}{l}\text { Aspek } \\
\text { Kontekstual }\end{array}$ & 3 & 3 & 3 & $\mathrm{~V} / \mathrm{PR}$ & 3 \\
\hline \multirow[t]{2}{*}{5} & Aspek & 4 & 3 & 3,5 & SV/TPR & \multirow[b]{2}{*}{3,5} \\
\hline & $\begin{array}{l}\text { Evaluasi dan } \\
\text { Umpan } \\
\text { Balik }\end{array}$ & 4 & 3 & 3,5 & SV/TPR & \\
\hline \multicolumn{2}{|c|}{ Nilai rata-rata } & 3,4 & $\begin{array}{l}\mathbf{3} \\
\mathbf{5}\end{array}$ & 3,4 & \multicolumn{2}{|c|}{3,4} \\
\hline
\end{tabular}

\section{Keterangan:}

$x_{1} \quad$ :validator media

$x_{2} \quad$ : validator materi

SV : sangat valid,

$\mathrm{V}$ : valid

KR : kurang valid

TV : tidak valid

TPR : tidak perlu revisi

PR : perlu revisi.

Hasil analisis validasi dari para ahli dosen dan guru pelajaran matematika SMK Muhammadiayh Kupang mendapatkan data bahwa, dilihat dari tabel 4.2 hasil uji validasi materi dan media diperoleh hasil penelitian 
dengan penilaian 5 aspek yaitu bahasa, contoh dan soal latihan, materi, kontekstual, evaluasi dan umpan balik. Hasil penilaian tersebut dengan rata-rata 3,4 karena nilai rata-rata $>3,25$ sehingga berada pada kategori sangat valid yang artinya dari segi 5 aspek tersebut media modul ini sangat valid dan sangat layak digunakan sebagai Bahan pembelajaran.

Tabel 2. Hasil Analisis Angket Respon Siswa pada Modul

\begin{tabular}{clll} 
No & Kriteria & $\begin{array}{c}\text { Rata-Rata } \\
\text { Tiap Aspek }\end{array}$ & Keterangan \\
\hline $\mathbf{1 .}$ & $\begin{array}{l}\text { Materi } \\
\text { pembelajaran }\end{array}$ & 3,58 & Sangat Baik \\
\hline $\mathbf{2 .}$ & Bahasa & 3,60 & Sangat Baik \\
\hline 3. & $\begin{array}{l}\text { Tujuan } \\
\text { pembelajaran }\end{array}$ & 3,56 & Sangat Baik \\
\hline Kesimpulan & $\mathbf{3 , 5 8}$ & $\begin{array}{l}\text { Sangat } \\
\text { Baik }\end{array}$ \\
\hline
\end{tabular}

Analisis lembar angket respon siswa terhadap modul terdapat aspek-aspek yang perlu diperhatikan dalam menganalisis antara lain: aspek materi pembelajaran, aspek bahasa dan aspek tujuan pembelajaran. Dari ketiga aspek terdapat beberapa sub-aspek yang dijabarkan pada pertanyaan nomor 1-15 dan diperoleh ratarata penilaian respon siswa dari 20 siswa adalah 3,58 sehingga ketiga aspek tersebut dapat dinyatakan mendapat respon sangat baik berdasarkan kategori yang telah ditetapkan.

Table 4.2 dapat dilihat kelima aspek materi dan media yang dinilai oleh 2 validator, secara umum dapat disimpulkan bahwa dari penjelasan 5 aspek diatas maka secara keseluruhan hasil penilaian ahli media dan materi pada "modul matematika dengan pendekatan metakognitif" dikatakan valid dengan rata-rata 3,4 . Kemudian setiap aspek yang dinilai oleh siswa mendapat respon sangat baik dari siswa, maka modul yang dikembangkan dinyatakan sangat praktis, efektif dan efisien berdasarkan respon siswa kelas X SMK Muhammadiyah Kupang dengan jumlah 20 siswa. Dengan demikian media pembelajaran ini sangat layak digunakan sebagai bahan ajar. Hal ini sejalan dengan pendapat (Zulfikar, 2019) yang berpendapat Pendekatan metakognoitif mempunyai peranan penting dalam membantu siswa menyelesaikan masalah matematika dan meningkatkan kemampuan representasi siswa, hal ini menunjukkan bahwa pemecahan masalah yang efektif dapat diperoleh dengan memberi kesempatan kepada siswa untuk menerapkan strategi metakognitif ketika memahami dan menyelesaikan soal matematika. Dengan media yang menarik siswa akah lebih mudah untuk memahami dan menangkap pesan dan informasi yang disampaikan oleh guru dalam proses pembelajaran, sehinggan tujuan dari pembelajaran dapat tercapai lebih optimal.

\section{SIMPULAN}

Dari penjelasan 5 aspek validasi maka secara keseluruhan hasil validasi penilaian media dan materi pada "modul matematika dengan pendekatan metakognitif" dikatakan sangat valid dengan rata-rata 3,4. Dengan demikian bahan ajar ini sangat layak digunakan sebagai bahan ajar. Hasil pengembangan modul dengan pendekatan metakognitif dapat juga dilihat dari repon siswa yaitu angket respon siswa menyebutkan bahwa didapat rata-rata 3,58 dan dapat dikategorikan mendapat respon sangat baik dari siswa. Karena rata-rata respon siswa sangat baik maka modul yang dikembangkan dapat dinyatakan berhasil berdasarkan respon siswa kelas X SMK Muhammadiyah Kupang dengan jumlah siswa 20 siswa. Berdasarkan kriteria keberhasilan modul dilihat dari rata-rata banyaknya siswa yang responnya sangat baik maka, media modul matematika dengan pendekatan metakognitif dapat dikatakan berhasil.

Dari pengembangan modul ini bisa memberikan informasi Bagi para guru mata pelajaran matematika, dan gambaran awal dalam pembuatan bahan ajar modul yang menarik, kreatif dan inovatif bagi para siswa.

\section{DAFTAR PUSTAKA}

Anisa.W.N, 2014. Peningkatan Kemampuan Pemecahan Masalah Dan Komunikasi Matematik Melalui Pembelajaran Pendidikan Matematika Realistik Untuk Siswa SMP Negeri Di Kabupaten Garut. Jurnal Pendidikan dan Keguruan, 1 (1)

Arsyad, A. 2011. Media Pembelajaran. Jakarta: Rajawali Pers.

Danuri. 2014. Pengembangan Modul Matematika Dengan Pendekatan Kontekstual Untuk Menfasilitasi Kemandirian Belajar Siswa SD/MI. Jurnal Pendidikan Dasar Islam, 6 (1).

In'am, A. 2012. Model Pembelajaran Matematika Berbasis Metakognitif. Malang: Selaras Perum Pesona Griya Asri 
Nugrahaningsih, T.K 2012. Metakognisi Dalam Pembelajaran Matematika Di SD. KNM $X v i$, Unpad, Jatinangor.

Rahmania. 2014. Peran Musyawarah Guru Mata Pelajaran Penjakes Dalam Penyusunan Rencana Pelaksanaan Pembelajaran Model Problem Based Learning (Pbl) Di Smp Negeri Dan Swasta Kota Banda Aceh. Jurnal Pencerahan, 8 (2)

Shimada, S. 2006. Senior Secondary Education Project 2006. The Open Ended Approach. A.

Zulfikar, RN. 2019. Pengaruh Pendekatan Metakognitif Terhadap Kemampuan Representasi Siswa Dalam Pembelajaran Matematika SMK Kesehatan Nusantara Kupang. Jurnal Inovasi Matematika (Inomatika) 1, (2) Hal 91-98 